\title{
Design and Evaluation of an Integrated FRP Composite Wicket Gate
}

\author{
P.V. Vijay ${ }^{a},{ }^{*}$, Piyush R. Soti ${ }^{\text {b }}$, Hota V. S. GangaRao ${ }^{c}$, Richard G. Lampo ${ }^{\mathrm{d}}$, and John D. Clarkson ${ }^{\mathrm{e}}$ \\ ${ }^{a}$ Asst. Professor, Dept. of Civil and Environmental Engineering (CEE), Constructed Facilities Center, West Virginia \\ University (WVU), Morgantown, WV 26506-6103 \\ ${ }^{\mathrm{b}}$ Graduate Research Asst., Dept. of CEE, WVU, Morgantown, WV 26506-6103 \\ ${ }^{\mathrm{c}}$ Director, Constructed Facilities Center, Dept. of CEE, WVU, Morgantown, WV 26506-6103 \\ ${ }^{\mathrm{d}}$ U.S. Army Corps of Engineers, Champaign, IL 61826-9005 \\ ${ }^{\mathrm{e}}$ U.S. Army Corps of Engineers, Huntington, WV 25701-2070 \\ *Corresponding author. Tel.: +13042939985, E-mail: p.vijay@mail.wvu.edu
}

\begin{abstract}
Hydraulic gates need to be light-weight, corrosion-resistant, maintenance-free, and durable with high endurance under fatigue loads. All of these requirements could be challenges to be met using conventional materials like steel and concrete. However, with the emergence of advanced Fiber Reinforced Polymer (FRP) composites for waterway structures, it has now been possible to achieve all of these physical and performance requirements in a cost-effective manner. Due to their lightness, excellent corrosion and wear resistance along with superior thermo-mechanical properties, FRPs have emerged as one of the best alternatives in the field of civil infrastructure. This paper covers several aspects of the design, manufacturing, testing, analysis, and field implementation of a novel integrated FRP wicket gate in Mississippi River lock and dam. The cellular FRP panel with foam core and integrated stiffening and fastening components has been analyzed to compute the bending stiffness both theoretically and experimentally and a good correlation has been obtained.
\end{abstract}

Keywords: cellular FRP deck, sandwich panel, deck stiffness, hydraulic structure, wicket gate

\section{Introduction}

The U.S. Army corps of Engineers (USACE) owns, operates and maintains an extensive infrastructure of navigational, flood control and waterfront structures over a length of 19,000 km (12,000 miles) in the United States. Most of these structures are made up of traditional materials such as steel, concrete and timber which are now exhibiting significant amount of corrosion, decaying and aging [1]. According to USACE, more than $\$ 13$ billion is required by 2020 to maintain existing levels of unscheduled delays on inland waterways without exacerbating further [2]. Almost 73\% of the budget is allocated to the rehabilitation of current lock and dam facilities [2]. Maintaining these steel, concrete and timber structures has become an arduous task as these materials are highly prone to undesirable deterioration under humid conditions in a short duration. Due to expensive regular maintenance and replacement costs of these structures combined with the recent advances in the development of fiber reinforced polymer (FRP) composites for use in civil engineering applications, USACE has shown interest in utilizing FRPs to minimize their construction and maintenance costs.

FRPs have been increasingly used for both rehabilitation and new construction in recent days due to their superior properties over conventional materials such as lightweight, high specific strength and resistance against corrosion, moisture and chemical attack [3-6]. They have proven their versatility and flexibility not only for ambient surface applications but also for fresh water and marine applications [4, 7-9]. Through this research, integrated wicket gates have been engineered with the use of noncorrosive FRP composites to mitigate extensive in-service maintenance and replacement of traditional timber and steel wicket gates in hydraulic locks and dams. FRPs are considered as one of the best alternatives to steel and timber in replacing hydraulic gates in locks and dams due to their excellent fatigue and wear resistance along with high durability $[6,10]$. 
In the past, FRP composites have been used in several demonstration projects for water environments [11-13]. They have proven their feasibility and efficacy as load bearing piles, fender piles and sheet piles in marine and waterfront environments [11]. FRPs have also been used as oil and gas storage tanks, decking for ocean environment and cold water pipes [12]. In Japan, more than four hundred FRP hydraulic gates including different styles of gates such as slide gate, roller gate, miter gate etc. have been installed since 1960s [13]. A field study conducted on 40-year old FRP gates in Japan has shown no major deterioration except little discoloration in the appearance, despite the gates requiring very little or no maintenance in the past [13]. Further, the specimens obtained from those old FRP gates were tested in the laboratory for water and corrosion resistance by Tomiyama and Nishizaki and the study confirmed their excellent durability [13]. FRPs have also been used in replacing old timber miter gates in Noord Brabant, Netherlands in 2000 with significant cost and weight reductions as compared to the conventional materials [14]. Similarly, FRP composite was used to replace steel miter gates in Canal des Voges, France. The largest FRP lock gate of size $10.5 \mathrm{~m} \mathrm{x} 13 \mathrm{~m}$ has been installed in the Wilhelmina canal in Tilburg, France [14-16]. Likewise, the research described in this paper describes designing, manufacturing, testing and field implementing of novel and integrated FRP wicket gates for lock and dam structures.

A wicket gate is a movable dam that is raised in times of low water and lowered when the water level is adequate for navigation. These gates have been utilized for navigation dams for over 100 years [17]. Although several types and designs of wicket gates have been utilized in the past, there are primarily two types of wicket gates. The first type is a bottom-hinged gate with a supporting prop and a remote-controlled hydraulic lifting system (Fig. 1a) and the second type is a horse type wicket gate which is supported by a horse and a prop-rod with manual lift (Fig. 1b).

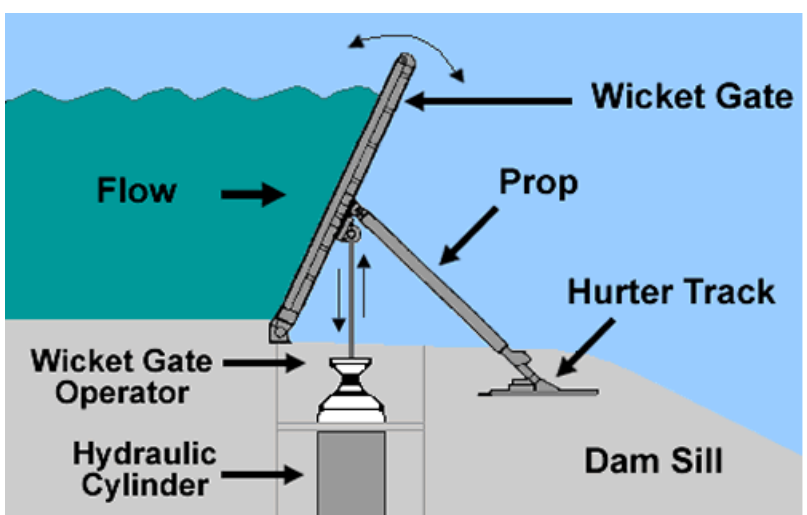

(a)

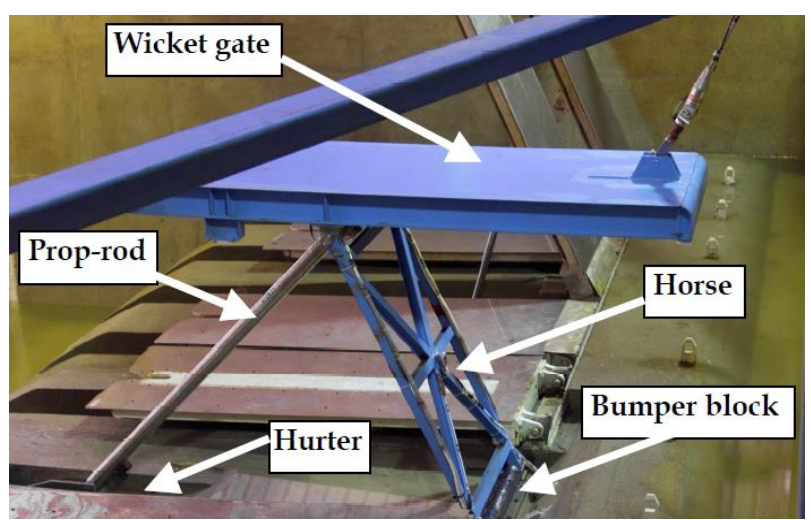

(b)

Fig. 1. Types of wicket gate configurations: a) first type, b) second type [17, 18]

FRP composites were previously used to manufacture wicket gates for replacing old and deteriorated timber wickets in Olmsted locks and dam in Ohio River in 1993 but were not field implemented for some undisclosed reasons [19, 20]. A single prototype wicket gate using FRP composite and steel was manufactured for Olmsted lock and dam and tested in the field for short duration. The testing of the gate showed larger deflections due to lower stiffness of FRP and gate sides were damaged due to debris getting caught between adjacent units [21]. The study conducted by Chaudhary et al. [22] on a scaled model of the FRP wicket gate showed no severe damages under highly abrasive loading conditions except peeling off on both edges due to high velocity of water flow between the panels [22]. The study suggested the use of local steel plates to minimize out of plane loading during lifting and addition of steel angles on the side panels to increase the durability [18]. Structures such as hydraulic gates have a tendency to exhibit self-excited vibrations during overflow and underflow scenarios. In order to study this phenomenon, Chaudhary et al. [18] tested a scaled model of FRP wicket gate to evaluate its dynamic performance [22]. The study indicated the absence of a dynamic resonance for wicket gates used in the field. Strain measurements and fatigue analysis of hinges and connecting pins of the gate system also showed no signs of overstressing of the wicket gate components [22]. Another study by Bejar and Hall [23] has described a mathematical model to estimate hydrodynamic forces on a wicket gate based on two-dimensional potential theory as described in section 3.4. 


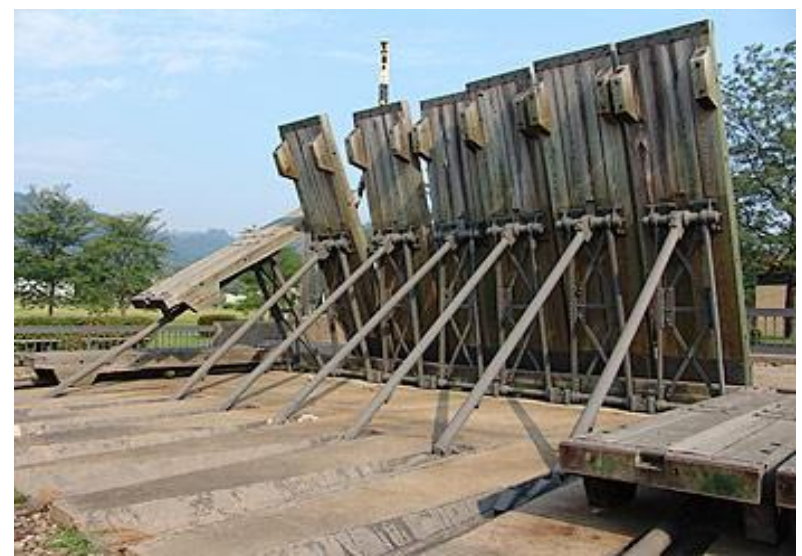

(a)

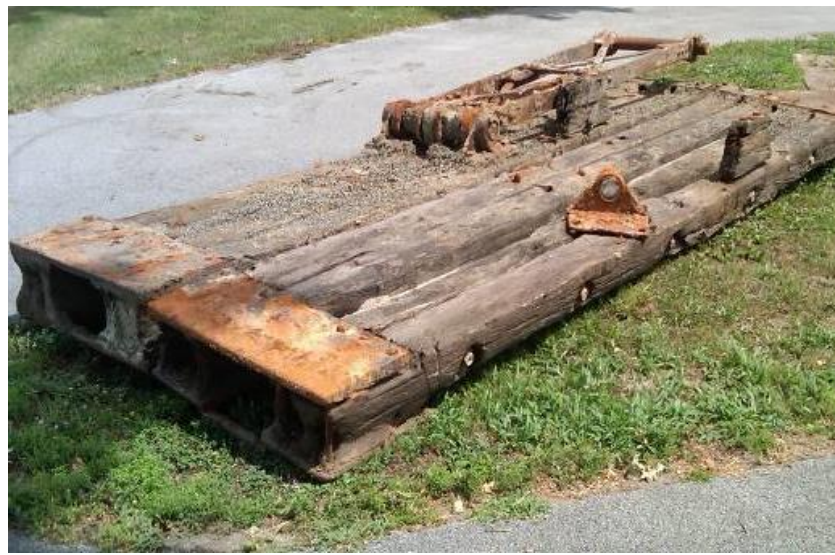

(b)

Fig. 2. a) Horse wicket gates (timber and steel) supported by prop rod, b) deteriorated timber wicket gates [19]

This research focuses on the design, analysis and manufacturing of horse type wicket gates. Size of wicket gate typically ranges from $1.2 \mathrm{~m}$ to $3 \mathrm{~m}$ ( 4 to $10 \mathrm{ft}$.) in width and $4.6 \mathrm{~m}$ to $6.1 \mathrm{~m}$ ( $15 \mathrm{to} 20 \mathrm{ft}$.) in length (height). These wicket gates are hinged individually just below their center point to the river bottom with the help of horse framing and are placed parallel across a navigation channel with $50 \mathrm{~mm}$ to $100 \mathrm{~mm}$ gap in-between and oriented at an angle of $65^{\circ}$ to form a dam (Fig. 2a). These gates are hoisted into position manually with a gantry operated crane or winch cable and are held in an upward position with a prop-rod that slides into a hurter. These gates are generally constructed with timber sections enclosed in steel or iron framing. Figure 2 (b) shows the amount of deterioration in a timber wicket gate after just 15 years of service life. Thus, there is a great need to invest on research and development of FRP composite gates in order to save huge costs associated with the periodical maintenance and replacement.

Based on the literature review, reverse engineering of current timber wicket gates and applying the basic principles of composite mechanics and structural analysis, integrated FRP composite wicket gates are designed to satisfy field requirement. The main objective of this research is to overcome disadvantages of conventional timber wicket gates such as heavy weight, susceptibility to corrosion, abrasion, decay and high maintenance or replacement by developing a light weight, corrosion resistant, decay-free and low maintenance FRP composite wicket gates for field implementation.

\section{In-service timber wicket gates of Rock Island lock and dam facility}

Wicket gates made of white oak timber sections with peripheral steel angle frames that are currently in service at Rock Island lock and dam, IL were considered for replacement with integrated FRP wicket gates as per discussion with USACE. The length (height) and width of this particular timber wicket gate is $5.03 \mathrm{~m}$ (16.5 ft.) and $1.17 \mathrm{~m}$ (3.83 ft.), respectively. The gate is made of four individual timber beams with varying depth along the length with the maximum depth being $305 \mathrm{~mm}$ (12") at nearly one-third height from bottom end under operating position. Peripheral steel angles measure $89 \mathrm{~mm}$ x $89 \mathrm{~mm} \times 6.35 \mathrm{~mm}(3.5$ " 3.5 " $\times 0.25 ")$ and are bolted to the edges of upstream face of the timber gate. Steel plates of size $12.7 \mathrm{~mm}$ x $152 \mathrm{~mm}(0.5$ "x6") and $45 \mathrm{~mm}$ x $458 \mathrm{~mm}$ (1.75"x18") are bolted on both upstream and downstream faces of the gate at the top and bottom, respectively (Fig. 3a). The downstream face of the gate consists of two steel plates of sizes $330 \mathrm{~mm} \times 432 \mathrm{~mm} \times 15.88 \mathrm{~mm}$ (13"x17"x 0.625 ") that are connected by a shaft to which a prop-rod of diameter $152 \mathrm{~mm}$ (6") gets connected as shown in Fig.3b.

The timber used in the gate had a design bending stress of $8.96 \mathrm{MPa}(1300 \mathrm{psi})$, shear stress of $1.41 \mathrm{MPa}$ (205 psi), compression perpendicular to grain of $5.52 \mathrm{MPa}(800 \mathrm{psi})$ and the modulus of elasticity of $12.27 \mathrm{GPa}(1.78 \mathrm{msi})$ as per NDS supplement for wood construction [24]. A moisture factor of 0.67 was used for compression perpendicular to grain. Using working stress method, allowable design values of the existing timber gate was found. The allowable compressive force on the gate through two steel plate attachments of sizes $330 \mathrm{~mm}$ x $432 \mathrm{~mm}$ (13" x 17") was 
$1054.23 \mathrm{kN}$ (237 kip), allowable shear force resisted by the gate was $333.62 \mathrm{kN}$ (75 kip), allowable punching shear through steel plates was $1312.23 \mathrm{kN}$ (295 kip), and allowable bending moment of a solid timber gate $1168 \mathrm{~mm} \mathrm{x}$ $305 \mathrm{~mm}$ (46"x12") without considering any steel plates was $161.34 \mathrm{kN}-\mathrm{m}$ (119 kip-ft). These reverse engineered values were used as a basis to design the FRP wicket gate.

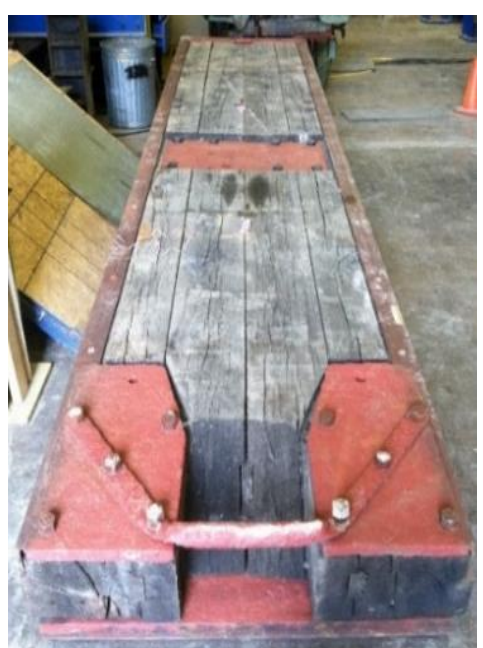

(a)

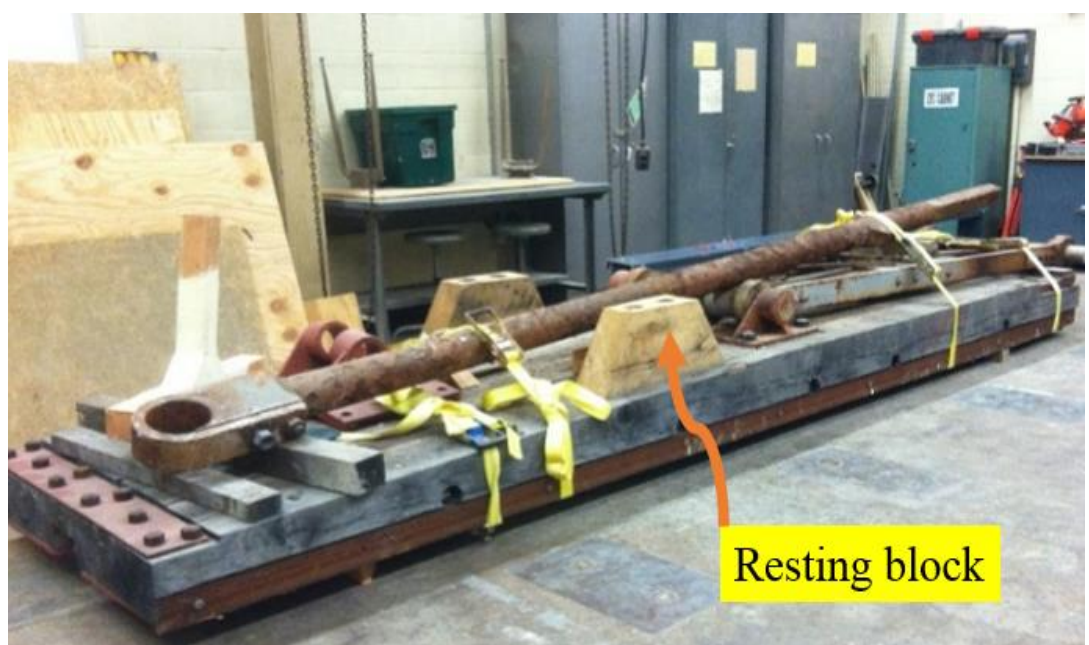

(b)

Fig. 3. Timber wicket gate: a) upstream face, b) downstream face with prop-rod on top

\section{Analysis of forces on wicket gate}

To facilitate wicket gate design, different loading scenarios were considered and the governing design forces were determined. The length and width of the gate are $5.03 \mathrm{~m}(16.5 \mathrm{ft}$.$) and 1.17 \mathrm{~m}(3.83 \mathrm{ft}$.$) , respectively and a prop-rod$ is connected to the middle portion (top hinge) of the gate as shown in Figure 4. The location of the top hinge from the bottom of the gate is $2.44 \mathrm{~m}(8 \mathrm{ft}$.) along the gate length (Fig. 4). For analysis, four loading scenarios were considered.
i. Operating position,
ii. Resting position,
iii. Lifting position, and
iv. Hydrodynamic forces

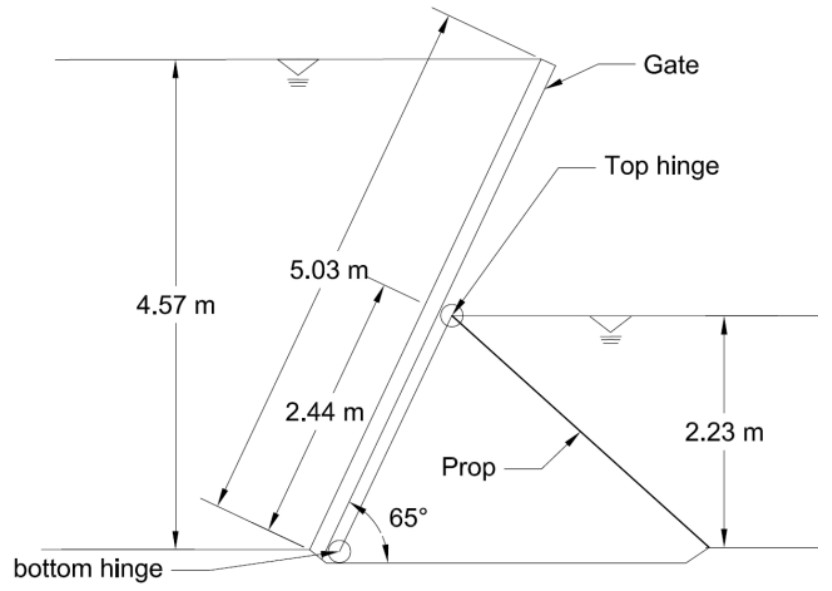

(a)

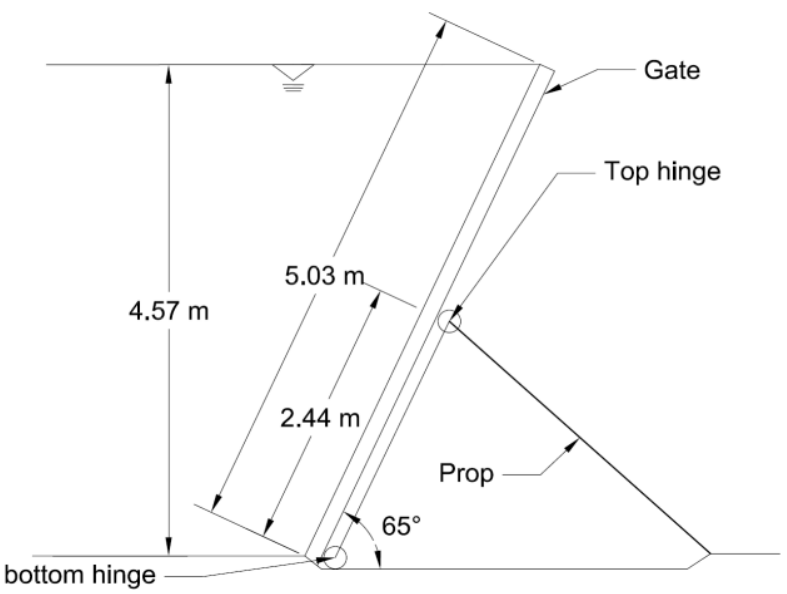

(b)

Fig. 4. Wicket gate in operating position: a) with tail water, b) without tail water

\subsection{Loads during operating position}


During operating position (Fig. 4), the maximum angle between the gate and the ground is $65^{\circ}$. The calculation of forces including self-weight and hydraulic pressure are based on two scenarios:

i) Presence of full height of water, i.e. $4.57 \mathrm{~m}$ (15 ft.) on upstream side (head water) and up to the height of the top hinge on downstream side (tail water), i.e., $2.23 \mathrm{~m}$ (7.3. ft.)

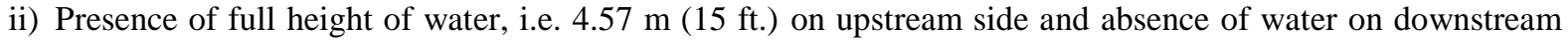
side

The self-weight of the FRP gate system is assumed as $26.7 \mathrm{kN}$ (6 kip) and considered to be acting through the center of the gate for the ease of calculation. The average water pressure and hydrostatic force on the gate surface were calculated by Eqns. (1) and (2). Equating moment of forces about bottom hinge (Fig. 4), forces in the prop and gate section were calculated as shown in Table 1.

Average water pressure on upstream side $=\frac{\gamma \mathrm{h}}{2}=\frac{9.81 * 4.57}{2}=44.8 \frac{\mathrm{kN}}{\mathrm{m}^{2}}$

Hydrostatic force on the upstream side $=44.8 \frac{\mathrm{kN}}{\mathrm{m}^{2}} \times 5.03 \mathrm{~m} \times 1.17 \mathrm{~m}=263.65 \mathrm{kN}$

\subsection{Loads during resting position}

During resting position on the river bed, the wicket gate stays on two support points, i) solid block and ii) bottom

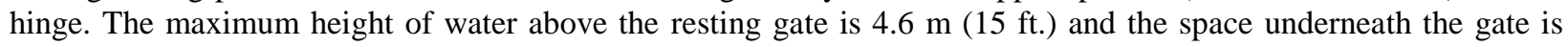
filled with water. Thus, equal pressure is exerted on both sides of the gate assuming the depth of the gate is insignificant. Therefore, wicket gate will have practically negligible loads during resting position and their negative buoyancy should be ascertained.

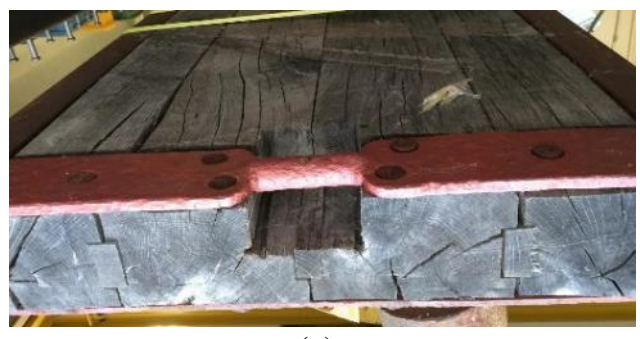

(a)

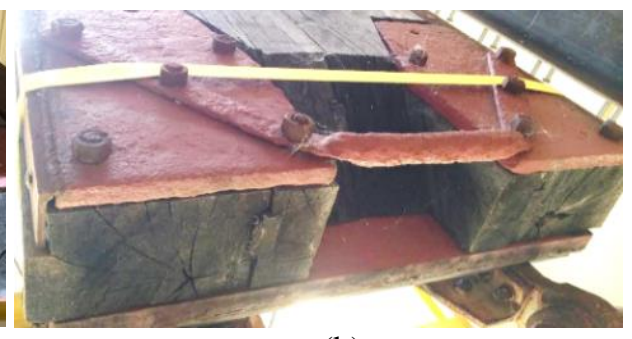

(b)

Fig. 5. Bails on the wicket gate: a) top bail, b) bottom bail

\subsection{Loads during lifting position}

During lifting, a winch cable is tied to either top or bottom bail (Fig. 5). In order to achieve higher safety factor and design for the worst possible scenario, the gate is assumed to act like a simply supported beam with the two ends

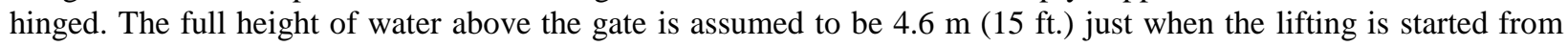
the rest position. It is also assumed that no pressure is exerted from the downstream side of the gate during lifting from resting position and the gate resists the entire flow of water over its surface. Computed maximum shear force and corresponding maximum bending moment are shown in Table 1.

\subsection{Loads due to hydrodynamic effects}

The presence of turbulent flow of water around the gate can create a scenario where each gate can be subjected to forces that can locally compound the mean induced stresses [25]. Researchers in the past have conducted mathematical modeling to determine hydrodynamic forces on the gate based on the results obtained from the experimental analysis on 1:25-scale physical model of the gate at the U.S. Army Engineer Waterways Experiment Station [23]. The largest hydraulic force acting on the single central gate for a closed position in a three-gate aperture condition as shown in the Fig. 6a, which means lowering of the adjacent gates on both sides of the test-gate. This configuration was identified from experiments on a corresponding 1:25-scale physical model as one of the critical conditions to be considered in the gate design [25]. The study conducted by Bejar and Hall, 1997 showed the resultant hydrodynamic force acting on the vertical projection of the gate and the vertical distance ( $\mathrm{z}$ ) at which it acts from the bottom of the gate based on Eqns. (3) and (4). 


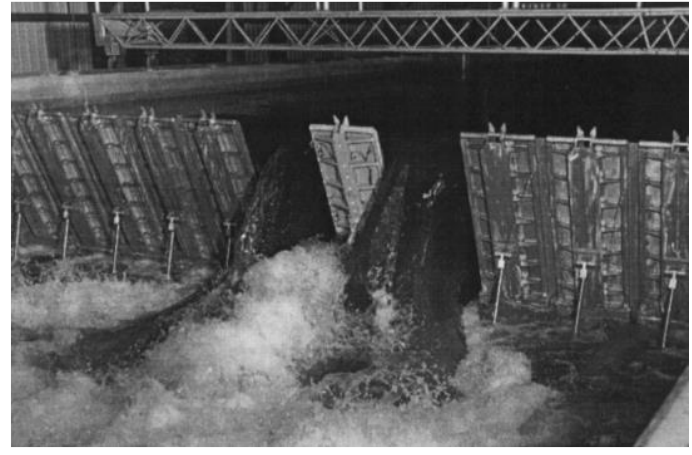

(a)

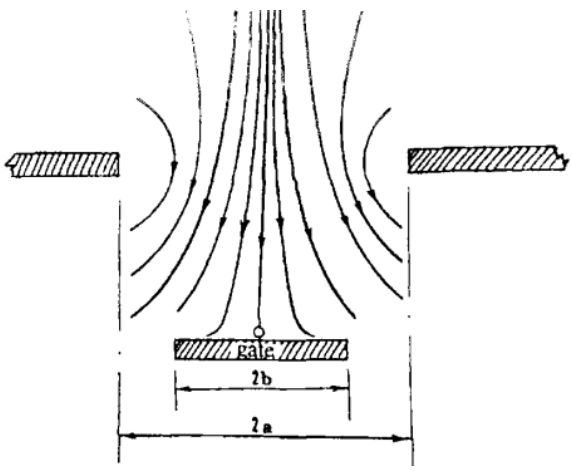

(b)

Fig. 6. a) Three-gate aperture, b) velocity field on upstream side of the gate [22, 25]

$F_{H}=\rho k_{d}^{2} * \frac{\pi}{2}\left(\frac{\pi}{2}+1\right) * \frac{A_{g}}{(2 a)^{2}} * \chi(\Delta \beta) * \sin \theta$

$z=0.58 h$

Where, $\rho$ is the density of water, $k_{d}$ is the coefficient of actual flow (length ${ }^{2} /$ time) obtained during experiment on the physical model, $A_{g}$ is the area of the upstream face of the gate, $2 a$ is the width of the test-gate including aperture on both sides, $h$ is the height of the vertical projection of the gate, $\Delta \beta$ is the hydrodynamic pressure distribution and $\theta$ is the inclination of the gate. $\chi(\Delta \beta)$ is the equivalent normalized distance of the gate as defined by Eqn. (5).

$\chi(\Delta \beta)=\frac{8(1-\Delta \beta)-1}{1+(1-\Delta \beta)}-\ln \left(\frac{2}{\Delta \beta}-1\right)=0.62$

For calculating the hydrodynamic resultant force for the wicket gate discussed in this paper, $k_{d}$ is taken as 0.0372 $\mathrm{m}^{2} / \mathrm{s}$ [25]. The area of the upstream face $\left(A_{g}\right)$ and the width $(2 a)$ of the gate including 2 " aperture on both sides for 1:25 scale model are taken as $0.009398 \mathrm{~m}^{2}$ and $0.0508 \mathrm{~m}$. Likewise, the hydrodynamic pressure distribution $(\Delta \beta)$ and $\chi(\Delta \beta)$ are taken as 0.15 and 0.62 , respectively. The inclination of the gate during the operating position is $65^{0}$. Therefore, the hydrodynamic resultant force for a 1:25 scale wicket gate model is provided by Eqns. (7) and (8) with appropriate scaling factor.

$F_{H}=1000 * 0.0372^{2} * \frac{\pi}{2}\left(\frac{\pi}{2}+1\right) * \frac{0.009398}{(0.0508)^{2}} * 0.62 * \sin 65=11.39 \mathrm{~N}$

$F_{H}=25^{3} * 11.39 N=178 \mathrm{kN}(40 \mathrm{kip})$

Hydrodynamic force of $178 \mathrm{kN}$ (40 kip) applied on the gate at a vertical height of $z=0.58 \mathrm{~h}$ for a height of $h=4.57 \mathrm{~m}(15 \mathrm{ft}$.) will result in a prop compressive force of $191.3 \mathrm{kN}$ (43 kip). Based on the analysis of above four scenarios, the design of FRP wicket gate is governed by the shear, compression and bending forces induced during lifting of the gate. Table 1 shows the summary of forces acting on the gate and governing forces which are accounted for with sufficient safety factors as discussed in section 4 .

Table 1

Summary of forces on wicket gate in different positions

\begin{tabular}{|l|l|l|l|l|}
\hline & Loading scenarios & $\begin{array}{l}\text { Prop force } \\
\text { kN (kip) }\end{array}$ & $\begin{array}{l}\text { Shear force on wicket } \\
\text { gate section, kN (kip) }\end{array}$ & $\begin{array}{l}\text { Bending moment on wicket } \\
\text { gate section, kN-m (kip-ft) }\end{array}$ \\
\hline 1 & Operating (with tail water) & $91.8(20.6)$ & $50.9(11.45)$ & $37.5(27.7)$ \\
\hline 2 & Operating (without tail water) & $102.3(23)$ & $40.9(9.2)$ & $27.7(20.4)$ \\
\hline 3 & Resting & 0 & 0 & 0 \\
\hline 4 & Lifting & 0 & $132(29.6)$ & $165.4(122)$ \\
\hline 5 & Hydrodynamic effects & $191.3(43)$ & $105.4(23.7)$ & $78.2(57.7)$ \\
\hline & Governing forces for design & $\mathbf{1 9 1 . 3 ( 4 3 )}$ & $\mathbf{1 3 2}(\mathbf{2 9 . 6})$ & $\mathbf{1 6 5 . 4 ( 1 2 2 )}$ \\
\hline
\end{tabular}




\section{Design of an integrated FRP wicket gate section}

In contrast to timber wicket gates consisting of four individual timber sections connected through bolts, FRP wicket gate was designed as a single sandwich section by integrating face sheets, webs and foam core. In addition, two steel plates were embedded inside face sheets which helped to enhance the moment of inertia of the section, reduce deflection and buoyancy and facilitate connectivity with existing horse and prop systems. Resting blocks (Fig. 2) were also integrated into the single FRP sandwich section which resulted in easier and stable assembly. Bolted steel angles on the sides of the wicket gate were replaced with the bonded ultra-high molecular weight polyethylene (UHMWPE) which helped reduce the use of steel and promised superior impact and abrasion performance. Negative buoyancy of the integrated FRP wicket gate was ensured through design and placement of embedded steel plates, core material and additional steel fixtures.

The cross-section of $215.5 \mathrm{~mm}$ (8.5") deep FRP composite wicket gate designed through this research is shown in Fig. 7. There are 14 webs across the $1.17 \mathrm{~m}$ (46") wide section wicket gate with top and bottom flange thickness of $13.28 \mathrm{~mm}(0.523$ ") each and web thickness of $10.16 \mathrm{~mm}(0.4$ ") each. Moment of inertia of a single FRP wicket gate module without steel attachments is $39,250.6 \mathrm{~cm}^{4}\left(943 \mathrm{in}^{4}\right)$. Timber wicket gates have additional steel attachments on top and bottom of the gate along with edge steel angles as shown in Figures 3 and 5, which contribute to the overall strength and stiffness of the gate. In this section, design checks have been performed on only FRP module without considering the additional strength and stiffness contributions from any steel attachments.

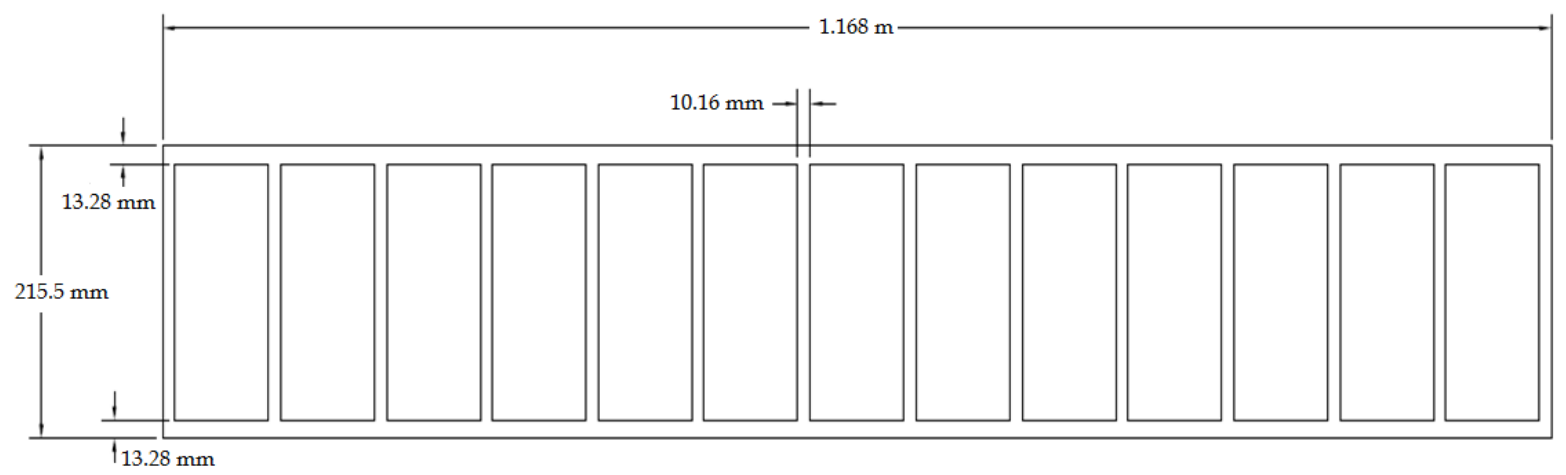

Fig. 7. Cross-section of FRP composite wicket gate without any steel attachment

\subsection{Check for bending stresses in the face sheet}

Bending stress in the face sheet $(\sigma)=\frac{\mathrm{Md}}{2 \mathrm{I}}=\frac{165.4 \mathrm{kNm} \times 215.5 \mathrm{~mm}}{2 \times 39250.6 \mathrm{~cm}^{4}}=45.5 \mathrm{MPa}(6.6 \mathrm{ksi})$

where, $\mathrm{d}$ is the depth of the section. Eqn. (8) gives a maximum bending stress of $45.5 \mathrm{MPa}$ (6.6 ksi) for the gate section. The failure bending stress of the FRP panel without any steel attachment is $196.5 \mathrm{MPa}$ (28.5 ksi), which is discussed in section 7.1. Based on this bending stress, total resisting bending moment of the selected FRP wicket gate is $696.6 \mathrm{kN}-\mathrm{m}$ (513.8 kip-ft.). Thus, a factor of safety of 4.3 against bending failure (196.5/45.5) is obtained. After considering a live load factor of 1.6, factor of safety against bending failure is 2.7 .

\subsection{Check for shear in webs}

Shear stress in the webs $(\tau)=\frac{1.5 \mathrm{~V}}{n_{w} t_{w} h}=\frac{1.5 \times 132 \mathrm{kN}}{14 \times 10.16 \mathrm{~mm} \times 202.2 \mathrm{~mm}}=6.88 \mathrm{MPa}(0.99 \mathrm{ksi})$

where, $n_{w}$ and $t_{w}$ are the number of webs and thickness of single web, respectively and $h$ is the height of webs between mid-planes of face sheets. Eqn. (9) gives a shear stress of $6.88 \mathrm{MPa}(0.99 \mathrm{ksi})$ across the wicket gate section. The in-plane failure shear strength of the FRP webs is established to be $113.1 \mathrm{MPa}$ (16.4 ksi) from manufacturer's test results. Based on this stress, factor of safety against shear failure is $16.4(113.1 / 6.88)$. 


\subsection{Check for web buckling}

Total prop force of $102.3 \mathrm{kN}$ ( $23 \mathrm{kip}$ ) is distributed to the gate through two plates of sizes $330 \mathrm{~mm} \mathrm{x} 432 \mathrm{~mm}(13$ " $\mathrm{x}$ 17 "). In each of this area, there are 4 webs of $10.16 \mathrm{~mm}(0.4$ ") thickness. Conservatively, considering total prop force coming to only one steel plate, each web is subjected to $26.7 \mathrm{kN}$ (6 kip). For an inch length of the web, moment of inertia about its minor axis is $2,218.5 \mathrm{~mm}^{4}\left(0.00533 \mathrm{in}^{4}\right)$. Considering the modulus of elasticity of the FRP webs to be of $24131.66 \mathrm{MPa}(3.5 \mathrm{msi})$, the buckling load for $25.4 \mathrm{~mm}(1$ ”) length of the web is given by Eqn. (10).

$\mathrm{P}_{\mathrm{cr}}=\frac{\pi^{2} \mathrm{EI}}{\mathrm{h}^{2}}=\frac{\pi^{2} \times 24131.66 \times 2218.5}{202.2^{2}}=12.9 \mathrm{kN}(2.9 \mathrm{kip})$

The buckling load for a single web of length $432 \mathrm{~mm}$ (17") underneath the steel plate is $219.3 \mathrm{kN}$ (49.3 kip), which gives a factor of safety of $8.2(219.3 / 26.7)$ for the webs against buckling. However, the factor of safety of FRP webs against buckling is more than 8.2 due to higher buckling load value of webs than $12.9 \mathrm{kN}$ ( 2.9 kip). Fixity of the webs near top and bottom face sheets will halve their effective height which will result in quadrupling of the buckling resistance.

\section{Theoretical calculation of strength and stiffness of FRP wicket gate section}

The designed cellular FRP sandwich deck consists of face sheets, primary and secondary webs, core material and embedded steel as shown in Fig. 8. In this section, the elastic analysis of sandwich cellular FRP deck with two embedded steel plates has been conducted. This analysis can be used to evaluate stresses in the face sheets, webs and core and also to calculate the flexural rigidity of the deck. The sandwich panel has a total width of $b$ and the depth of $d$. The face sheets, primary webs and secondary webs have thicknesses $t_{f}, t_{p w}$ and $t_{s w}$, respectively. The core material have a thickness $c$ and two embedded steel plates have width $b_{s}$ and thickness $t_{s}$, as shown in Fig. 8 .

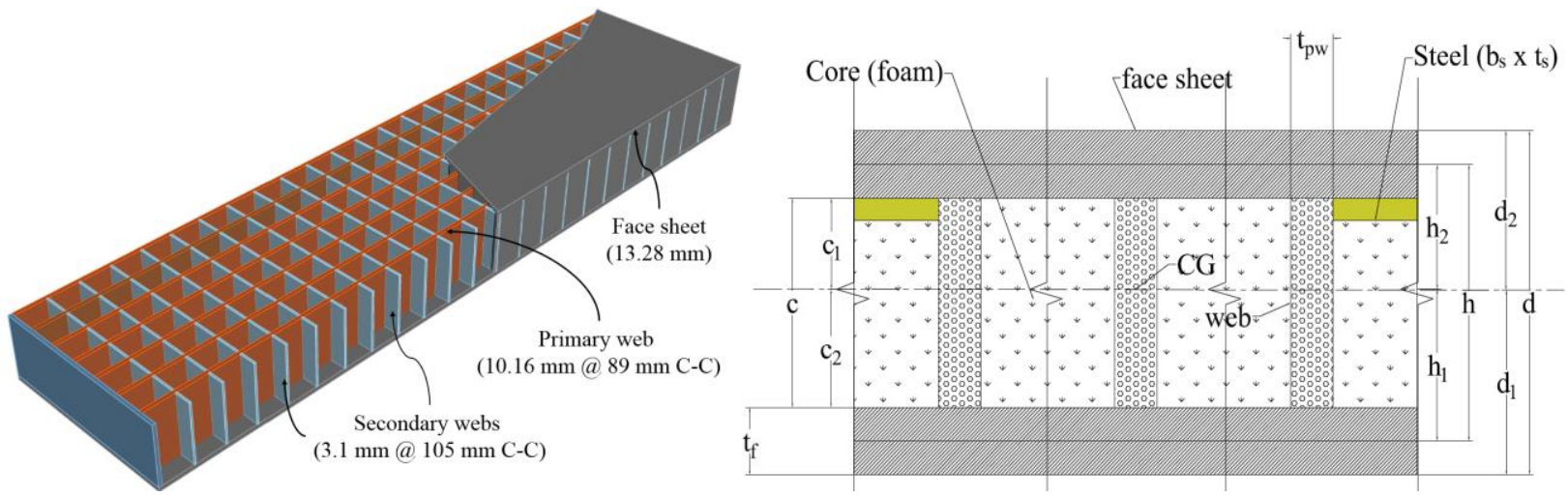

Fig. 8. Cellular FRP sandwich deck: a) $14^{\text {th }}$ model with primary and secondary webs, b) part of the cross section

During bending, it is assumed that the face sheets remain bonded to the core and the section bends with no curvature in the YZ-plane and the cross-section of the panel remains perpendicular to the longitudinal axis. The flexural rigidity $D$ of the sandwich cellular FRP panel section in the longitudinal direction is given by the algebraic summation of longitudinal stiffnesses of face sheets, primary webs, core and embedded steel plates as shown in Eqns. (11) to (14). The contribution of secondary webs to the flexural rigidity in the longitudinal direction is less and can be neglected.

$D_{\text {face sheets }}=\frac{E_{f x} b t_{f}{ }^{3}}{6}+E_{f x} b t_{f}\left(h_{1}{ }^{2}+{h_{2}}^{2}\right)$
$D_{\text {primary webs }}=\frac{n_{p w} E_{p w x} t_{p w}\left(h_{1}+h_{2}\right)^{3}}{12}+n_{p w} E_{w x} t_{p w}\left(h_{1}+h_{2}\right)\left(d_{1}-\frac{d}{2}\right)^{2}$ 
$D_{\text {core }}=\frac{E_{c x}\left(b-n_{p w} t_{w}\right) c^{3}}{12}+E_{c x}\left(b-n_{p w} t_{w}\right) c\left(c_{1}-\frac{c}{2}\right)^{2}$

$D_{\text {embedded steel }}=\frac{E_{s} b_{s} t_{s}{ }^{3}}{12}+E_{s} b_{s} t_{s}\left(d_{2}-t_{f}-\frac{t_{s}}{2}\right)^{2}$

Where, $h_{1}$ and $h_{2}$ are distances between center of gravity (CG) of the panel and the mid-planes of upper and bottom face sheets, respectively. $d_{1}$ and $d_{2}$ are distances between CG of the panel and the bottom and top of the face sheets, respectively and $c_{1}$ and $c_{2}$ are distances between $\mathrm{CG}$ of the panel and the bottom and top of the foam core as shown in Fig. 8. Likewise, $n_{p w}$ denotes the number of primary webs in the section. $E_{f x}, E_{p w x}, E_{c x}$ and $E_{s}$ are the in-plane young's moduli of the face sheet, primary webs, core and steel respectively along the longitudinal axis of the panel. The first term of Eqns. (11) to (14) corresponds to the bending of the respective sections about their own centroid axes, while the second term corresponds to the bending about the centroid axes of the whole panel section. When the modulus of elasticity of the core material is very less compared to that of the panel, its contribution to the flexural rigidity of the entire panel section can be neglected. The contributions from the first term of Eqns. (11), (14) and second term of Eqn. (12) are also negligible. Thus, the flexural rigidity or the bending stiffness of the sandwich cellular FRP panel with embedded steel plates can be simplified as shown by Eqn. (15).

$D_{x}=E_{f x} b t_{f}\left(h_{1}{ }^{2}+h_{2}{ }^{2}\right)+\frac{n_{w} E_{w x} t_{p w}\left(h_{1}+h_{2}\right)^{3}}{12}+E_{s} b_{s} t_{s}\left(d_{2}-t_{f}-\frac{t_{s}}{2}\right)^{2}$

The out-of-plane shear stiffness of the cellular FRP sandwich deck in the longitudinal direction $\left(F_{x}\right)$ is expressed as:

$F_{x}=n_{p w} G_{p x y} t_{p w} h$

Where, $G_{p x y}$ is the in-plane shear modulus of primary webs and $h$ is the depth of the web between the mid-planes of face sheets. The transverse bending stiffness of the cellular FRP sandwich deck is mainly achieved from the bending stiffnesses of the face sheets and the secondary webs as shown by Eqn. (17). The effects of primary webs and second moment of area of face sheets about their own centroids are neglected.

$D_{y}=E_{y} l t_{f}\left(h_{1}{ }^{2}+h_{2}{ }^{2}\right)+\frac{n_{s w} E_{s w x} t_{s w}\left(h_{1}+h_{2}\right)^{3}}{12}$

Where, $E_{y}$ is the modulus of elasticity of the panel in y-direction, $l$ is the length of the panel in longitudinal direction, $n_{s w}$ and $t_{s w}$ are the number and thickness of secondary webs in the section and $E_{s w x}$ is the in-plane young's modulus of the secondary webs. Similarly, the transverse shear stiffness $\left(F_{y}\right)$ for the cellular FRP sandwich section can be obtained by considering the structure as a vierendeel frame in the transverse direction [27].

$F_{y}=n_{s w} G_{s x y} t_{s w} h+\frac{12 E_{y}}{b\left(\frac{h}{I_{w}}+\frac{b}{2 I_{f}}\right)}$

Where, $G_{s x y}$ is the in-plane shear modulus of secondary webs and the moment of inertias are defined as:

$I_{f}=\frac{l t_{f}{ }^{3}}{12} ; I_{w}=\frac{l t_{w}{ }^{3}}{12}$

The theoretical bending and shear stiffnesses of cellular FRP sandwich deck panel were verified with experimental results obtained from 3-point and 4-point bending tests of the panel in later sections. The central deflection of the deck can be computed from their corresponding bending and shear stiffnesses as shown in Eqns. (20) and (21).

$\delta=\frac{P L^{3}}{48 D_{x \text { or } y}}+\frac{P L}{4 \kappa F_{x \text { or } y}}(3$-point bending $)$

$\delta=\frac{23 P L^{3}}{1296 D_{\text {x or } y}}+\frac{P L}{6 \kappa F_{x \text { or } y}}(4$-point bending $)$ 
Where, $P$ is the total load applied, $L$ is the length of the span, $\kappa$ is the shear correction factor (assumed as 1.00 in this analysis) and $D, F$ are the bending and shear stiffness in either longitudinal or transverse direction based on loading and support conditions.

\section{Manufacturing of an integrated FRP wicket gate}

The FRP composite wicket gate was manufactured by using vacuum assisted resin infusion process (Fig. 9). The reinforcement in the face-sheet skins and webs are E-glass fiberglass fabrics. Wicket gate face sheet skins and webs consisted of highly directional E-glass fabrics with fibers running primarily in the $0^{\circ}$ direction along the length of the gate for resisting bending loads and tri-axial fabrics with fibers in the $\pm 45^{\circ}, 90^{\circ}$ directions for resisting in-plane shear and transverse forces. Wicket gate consisted of thirteen closed cells and water resistant web cores. Web cores used in the panel were reinforced with $\pm 45^{\circ}$ fabrics which when infused with resin formed very strong and stiff shear webs for the sandwich cross-section. Closely spaced webs provide very good crushing resistance to potential concentrated loads. Local skin deflections are generally assumed negligible when the face sheet is supported by the webs. The redundancy of multiple webs provides improved damage tolerance as compared to thick and widerspaced webs.

The fiber/fabric layup of the composite top and bottom face sheets are symmetric to middle surface with "Composite Advantage ${ }^{8}$ bidirectional core" at the center. Symmetric layers from outside to inside are $0.75 \mathrm{oz}$ CFM (nonstructural), $55 \mathrm{oz}$ unidirectional $\left(0^{\circ}\right), 40 \mathrm{oz}$ triaxial $\left(90^{\circ}\right), 40 \mathrm{oz}$ triaxial $\left(0^{\circ}\right), 55 \mathrm{oz}$ unidirectional $\left(0^{\circ}\right), 40 \mathrm{oz}$ triaxial $\left(90^{\circ}\right), 40 \mathrm{oz}$ triaxial $\left(0^{\circ}\right), 55 \mathrm{oz}$ unidirectional $\left(0^{\circ}\right), 40 \mathrm{oz}$ triaxial $\left(90^{\circ}\right), 40 \mathrm{oz}$ triaxial $\left(0^{\circ}\right)$ and $55 \mathrm{oz}$ unidirectional $\left(0^{\circ}\right)$ fabrics.

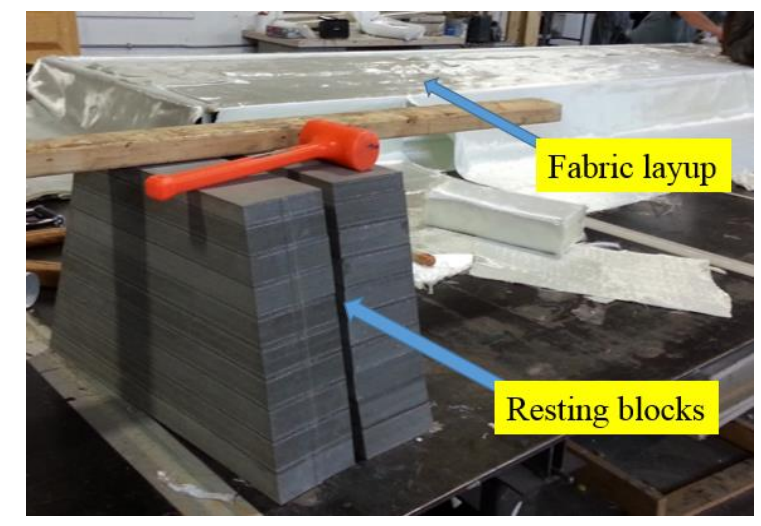

Fig. 9. Manufacturing of FRP wicket gate on a molding table with resting block core

\section{Testing and Results}

Laboratory tests were performed on FRP coupon specimens, timber and FRP wicket gates. Loading levels were within $40 \%$ of the ultimate loads. Bending and shear strains were measured both on the upstream and downstream sides of the gate at the center of the panel and hinge and prop locations. Deflections were measured through LVDTs. Shear gages were instrumented on side walls. During reverse engineering analysis, it was found that the bending loads were more critical as compared to shear. Following tests were performed in the laboratory:

i. Tensile test on FRP wicket gate coupon specimens

ii. Four point bending test on timber wicket gate and FRP wicket gate with steel fixtures

iii. Three point bending test on FRP wicket gate after removing steel fixtures

iv. Fatigue test on FRP wicket gate

v. End plate/bail pull test 


\subsection{Tensile test on FRP wicket gate coupon specimens}

Tensile tests were conducted on FRP coupon specimens representing face sheet of the FRP wicket gate to obtain modulus of elasticity (E) of the FRP laminate. These face sheet coupons were selected to represent smooth and potential wrinkling near the outer surfaces or edges (Fig. 10). Samples with dimensions of $1067 \mathrm{~mm} \times 50.8 \mathrm{~mm} \times$ $10.9 \mathrm{~mm}$ in the longitudinal and transverse directions were prepared and tested in tension. The strain gages were located at the mid-height region of the sample. Table 2 shows the test results and Fig. 10 shows the stress vs. strain plot for specimens with and without wrinkling in the longitudinal direction. The modulus of elasticity for both types of specimens was identified and found to be $30.34 \mathrm{GPa}(4.4 \mathrm{msi})$.

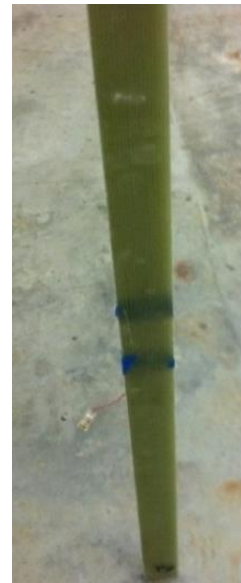

(a)

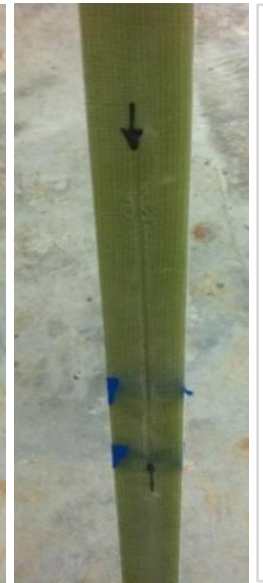

(b)

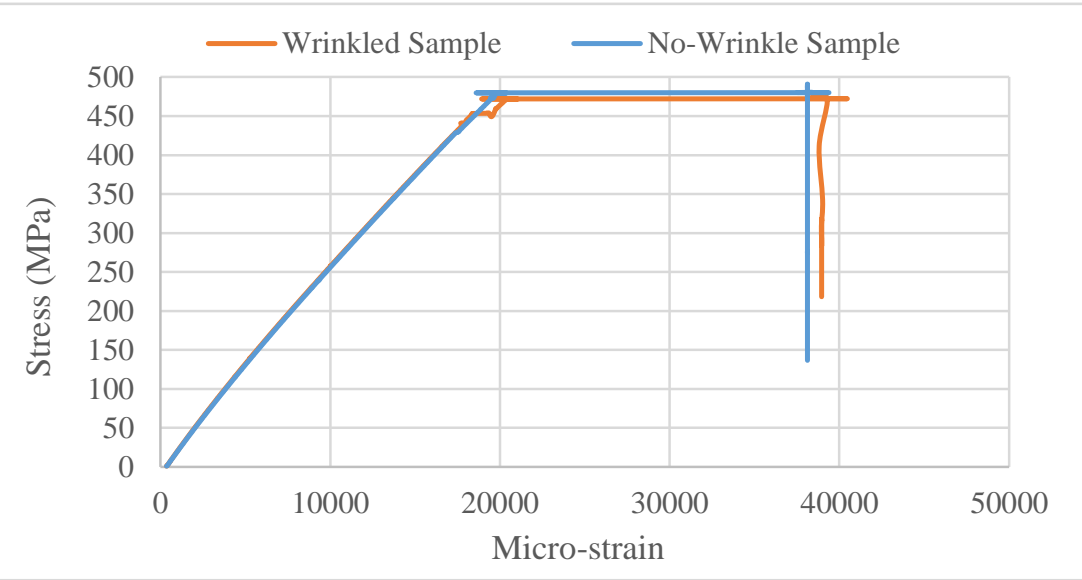

(c)

Fig. 10. a) no-wrinkle sample, b) wrinkled sample, c) stress vs. strain plot for long direction for both samples

\section{Table 2}

Tensile stress and stiffness of face sheet coupon specimens with and without surface wrinkles

\begin{tabular}{|c|c|c|c|c|c|c|c|}
\hline Sample & Wrinkle & $\begin{array}{c}\text { Width } \\
\mathrm{mm}(\mathrm{in})\end{array}$ & $\begin{array}{c}\text { Thickness } \\
\mathrm{mm}(\mathrm{in})\end{array}$ & $\begin{array}{c}\mathrm{C} / \mathrm{S} \text { area } \\
\mathrm{mm}^{2}\left(\mathrm{in}^{2}\right)\end{array}$ & $\begin{array}{c}\text { Avg. peak load } \\
\text { kN (kip) }\end{array}$ & $\begin{array}{c}\text { Avg. stress } \\
\text { MPa (ksi) }\end{array}$ & $\begin{array}{c}\text { Stiffness } \\
\text { GPa (msi) }\end{array}$ \\
\hline $\begin{array}{c}\text { Longitudinal } \\
\text { (along length) }\end{array}$ & No & $50.8(2)$ & $10.9(0.43)$ & $555.5(0.86)$ & $272.7(61.3)$ & $490.9(71.2)$ & $30.34(4.4)$ \\
\cline { 2 - 8 } & Yes & $50.8(2)$ & $10.9(0.43)$ & $555.5(0.86)$ & $272.2(61.2)$ & $490.2(71.1)$ & $30.34(4.4)$ \\
\hline $\begin{array}{c}\text { Transverse } \\
\text { (along width) }\end{array}$ & No & $50.8(2)$ & $10.9(0.43)$ & $567.7(0.88)$ & $138.8(31.2)$ & $250.3(36.3)$ & - \\
\cline { 2 - 8 } & & & &
\end{tabular}

The tensile strain to failure for the coupon specimens is 18,000 micro-strain as seen in Fig. 10. Bending failure stress of the entire panel was obtained by applying a knock-down factor of 0.6 and a stress concentration factor of 0.6 which leads to the bending strain to failure of the gate as 6,480 micro-strains. Thus, stress to failure for bending is given by Eq. (22).

Bending stress to failure $=30.34 \mathrm{GPa} * 6480 \times 10^{-6}=196.5 \mathrm{MPa}(28.5 \mathrm{ksi})$

\subsection{Four point bending test on timber wicket gate and FRP wicket gate with steel fixtures}

Four-point bending loads were applied at L/3 distance from both ends of the FRP gate without removing external steel fixtures (Fig.11). These fixtures such as steel edge angles and connecting plates (top and bottom) enhance flexural rigidity and provide abrasion resistance. Five shear strain gages and 15 axial strain gages were bonded at different locations of the gate and LVDTs were used to measure deflections. Load of $267 \mathrm{kN}$ (60 kip) each was applied with two MTS hydraulic actuators at L/3 distance for FRP wicket gate and similar load of $155.7 \mathrm{kN}$ (35 kip) each was applied to the timber wicket gate. Table 3 shows the results of the testing. The maximum bending strains at $\mathrm{L} / 2$ (center) and L/3 distances were 3352 micro-strains and 2001 micro-strains, respectively. Maximum shear strain of 2230 micro-strains was measured at a distance ' $d$ ' from the support, where ' $d$ ' is the gate depth. Strains during bending failure in FRP shapes is noted to be in the range of 10,000 to 15,000 micro-strains and in the range of 8000 
to 10,000 micro-strains during shear failure. These induced strains are about $1 / 4$ th to $1 / 3 \mathrm{rd}$ of the failure strains but may vary based on the fiber-fabric architecture, L/d ratio, and local failure modes.

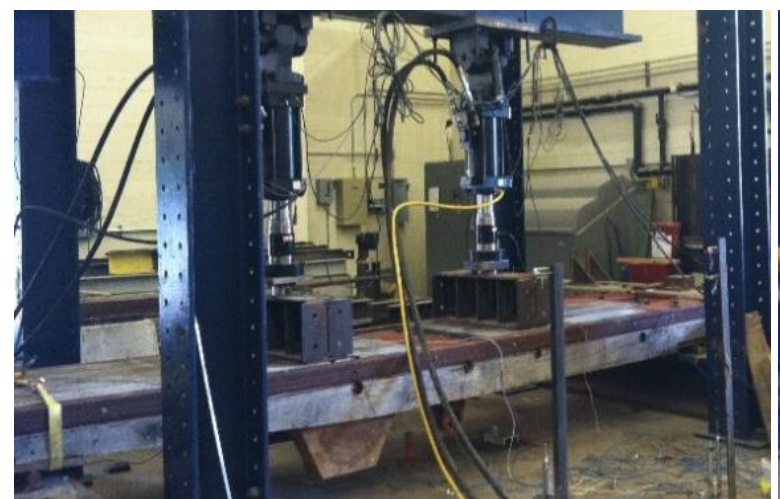

(a)

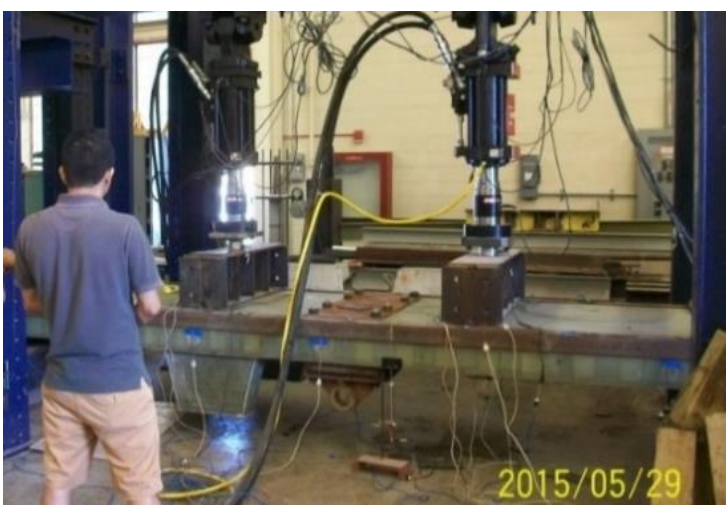

(b)

Fig. 11. Bending tests: a) on timber wicket gate, b) on FRP wicket gate

Table 3

Four-point bending test results of timber and FRP gate

\begin{tabular}{|l|c|c|}
\hline \multicolumn{1}{|c|}{ Items } & Timber gate & FRP gate \\
\hline Test span, m (ft.) & $4.57(15)$ & $4.57(15)$ \\
\hline Load distance from supports, m (ft.) & $1.52(5)$ & $1.52(5)$ \\
\hline Total load, kN (kip) & $311.4(70)$ & $534(120)$ \\
\hline Maximum moment, kN-m (k-ft) & $237.3(175)$ & $406.7(300)$ \\
\hline Maximum bending strain at center (micro-strain) & 1312 & 3352 \\
\hline Maximum shear strain (micro-strain) & 129 & 2230 \\
\hline Maximum deflection at center (L/2), mm (inches) & $26.42(1.04)$ & $58.75(2.313)$ \\
\hline Maximum deflection at L/3, mm (inches) & $24.13(0.95)$ & $51.8(2.04$ ') \\
\hline
\end{tabular}

\subsection{Three point bending test on FRP wicket gate without steel fixtures}

After removing steel fixtures, FRP wicket gate was loaded in 3-points for a span of $4.57 \mathrm{~m}$ (15 ft.) with a load of 89 $\mathrm{kN}$ (20 kip) as shown in Fig. 12. Strains were measured at different locations of the gate and the vertical displacements were measured at the center and one-third distance. At the maximum load of $89 \mathrm{kN}$, the maximum deflection obtained at the center and one-third of the span was $14.81 \mathrm{~mm}(0.583$ ") and $12.78 \mathrm{~mm}(0.503$ "), respectively.

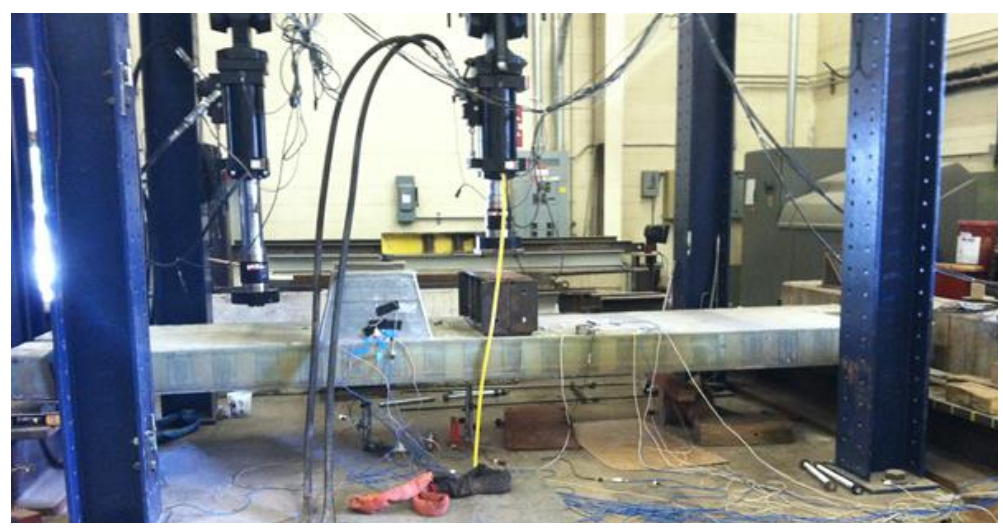

Fig.12. Three point bending test of FRP wicket gate 


\subsection{Fatigue test on FRP wicket gate}

FRP wicket gate, without any steel fixtures, was tested in fatigue with a load-range of 53.4 to $106.8 \mathrm{kN}$ (12-24 kip)

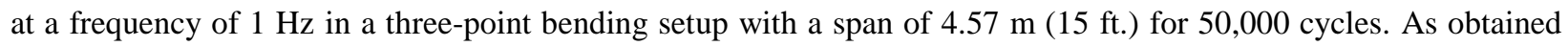
from USACE, the gate operating sequences are based on seasonal variations of water level and are highly unlikely to exceed 5,000 cycles in a 100-year life cycle. For a typical FRP material, applied stress (S) vs. number of cycles (N), i.e., S-N curve can be expressed in a linear manner as shown in Eqn. (23), when the number of cycles is less than one million cycles $[28,29]$.

$\frac{\sigma_{\text {applied }}}{\sigma_{\text {static }}}=A+B \log N$

where, $\sigma_{\text {applied }}$ is the applied stress or stress range, and $\sigma_{\text {static }}$ is the ultimate static strength. $A$ and $B$ are material constants. At a very low stress range, the S-N curve gets flattened indicating the infinite life of the material [29]. For the FRP wicket gate designed in this research, the maximum load that gets transferred to the gate through prop rod via prop connecting steel plates during operating position is $91.8 \mathrm{kN}$ (20.6 kip) (Table 1), therefore the load applied on the gate was in the range of 53.4 to $106.8 \mathrm{kN}$ (12-24 kip), where the maximum stress applied to the gate is just $17 \%$ of its ultimate strength. Generally, this limit of stress falls below the endurance limit for FRP composites and at this stress, the fatigue life of the FRP material is considered to be infinite [30,31]. In addition, after 50,000 cycles of loading, three-point static bending test was performed on the gate with the central load of $178 \mathrm{kN}$ (40 kip). The maximum tensile strain obtained at the center of the gate was 975 micro-strains compared to 978 micro-strains before fatigue. The strain levels indicated that the stiffness and strain energy absorption capacity of the gate was not reduced due to fatigue loading and will not be affected during its service life.

\subsection{End plate/bail pull test}

FRP wicket gate was placed horizontally on two end supports with top of the gate fixed against horizontal movement. A chain was attached to the top bail (weaker than the bottom bail) and pulled horizontally with a force of $84.1 \mathrm{kN}$ (18.9 kip) (Fig. 13). The pulling force on the bail is transferred to the FRP face sheets through the bolt attachments. Few strain gages bonded to the FRP surface below the bail recorded a maximum strain of 104 microstrains. These low strains indicate that the gate can safely withstand the bail pullout forces with a high factor of safety.

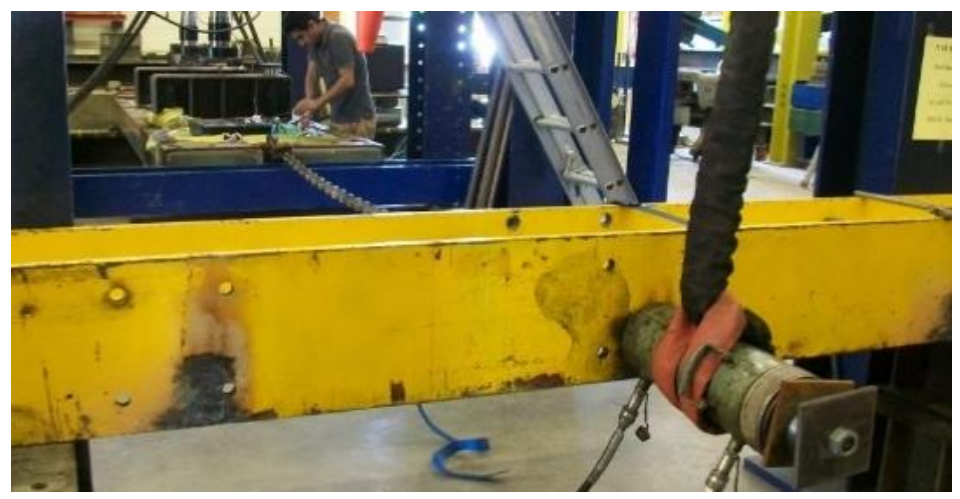

Fig. 13. Pulling of the FRP gate with the chain attached to the top bail

\section{Stiffness of the FRP wicket gate}

In this section, the stiffness of the FRP wicket gate is experimentally evaluated and compared with the theoretical value. Center of gravity (c.g.) of the wicket gate with two embedded steel plates is calculated as shown in Table A1 (Appendix A). Low stiffness of the core material (foam) is ignored in the calculations. Two embedded steel plates act compositely with the FRP section. Using a stiffness (E) value of $28.3 \mathrm{GPa}(4.1 \mathrm{msi})$ for face sheets and primary webs, a modular ratio of 7.1 was obtained for steel plates embedded in the integrated FRP wicket gate. The density 
of steel plates is $7861 \mathrm{~kg} / \mathrm{m}^{3}\left(0.284 \mathrm{lbf} / \mathrm{in}^{3}\right)$ as compared to $996.5 \mathrm{~kg} / \mathrm{m}^{3}\left(0.036 \mathrm{lbf} / \mathrm{in}^{3}\right)$ for FRP composites. It is necessary to compute composite moment of inertia of the FRP cellular deck including embedded steel attachment in order to find the overall stiffness of the FRP gate. The composite moment of inertia has been computed and shown in Table A2 of Appendix A.

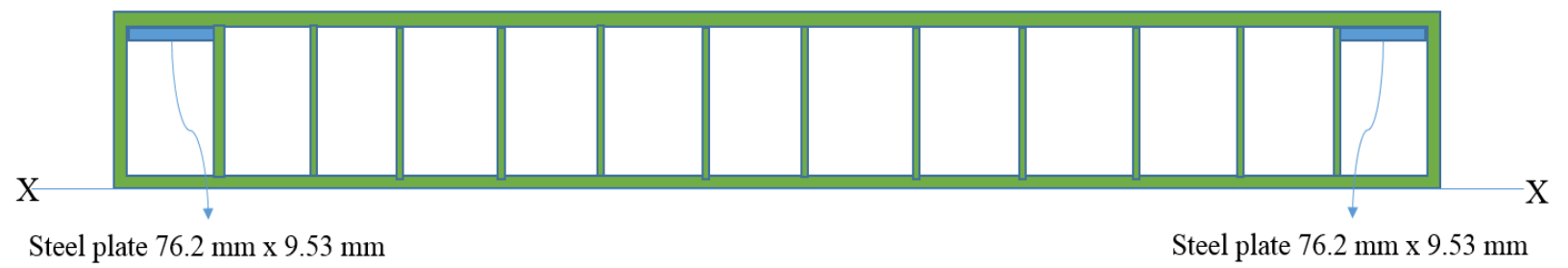

Fig. 14. Cross-section of a FRP wicket gate with embedded steel plates

The center of gravity of the cellular FRP section with embedded steel plates is located at distance of $134.1 \mathrm{~mm}$ (5.28”) from the surface marked as X-X in Fig. 14 and the total moment of inertia is $481.1 \times 10^{6} \mathrm{~mm}^{4}\left(1155.8 \mathrm{in}^{4}\right)$ (Appendix A). From 3-point bending tests on the FRP wicket gate (see section 7.3) without steel fixtures, the total deflection of $14.81 \mathrm{~mm}(0.583$ ") was obtained for a span of $4.57 \mathrm{~m}$ (15 ft.) and a central load of $89 \mathrm{kN}$ (20 kip). By using Eqn. (20), the total deflection is separated into bending and shear deflections. With a shear modulus of 3.1 GPa (447 ksi) for FRP primary webs, the shear stiffness of the cellular FRP gate in the longitudinal direction is obtained as $88822.1 \mathrm{kN}\left(1.997 \times 10^{7} \mathrm{lbs}\right.$.) based on Eqn. (16).

After accounting for shear related deflection, the experimental bending rigidity is $1.31 \times 10^{13} \mathrm{~N} \cdot \mathrm{mm}^{2}\left(4.55 \times 10^{9} \mathrm{lbf}\right.$. $\mathrm{in}^{2}$ ), which correlates well with the theoretical bending rigidity calculated using Eqn. (15) (Table 5). Addition of steel fixtures (edge angles and connecting plates) increased the flexural rigidity to $1.67 \times 10^{13} \mathrm{~N} \cdot \mathrm{mm}^{2}\left(5.82 \times 10^{9} \mathrm{lbf}\right.$ in $^{2}$ ) which resulted in a $28 \%$ gain.

Table 5

Flexural rigidity and Stiffness of the cellular FRP wicket gate

\begin{tabular}{|c|c|c|c|c|c|c|c|}
\hline Bending test & $\begin{array}{c}\text { Central } \\
\text { load } \\
\mathrm{kN} \text { (kip) }\end{array}$ & $\begin{array}{l}\text { Central } \\
\text { deflection } \\
\text { mm (in) }\end{array}$ & $\begin{array}{c}\text { Experimental } \\
\text { flexural } \\
\text { rigidity (D) } \\
\text { N.mm² } \\
\left(\text { lbf.in }{ }^{2}\right)\end{array}$ & $\begin{array}{l}\text { Theoretical } \\
\text { flexural } \\
\text { rigidity (D) } \\
\text { N.mm }{ }^{2} \\
\left(\text { lbf.in }{ }^{2}\right) \\
\text { (Eqn. 15) }\end{array}$ & $\begin{array}{c}\text { Experimental } \\
\text { stiffness } \\
(\mathrm{E}) \\
\mathrm{GPa}(\mathrm{msi})\end{array}$ & $\begin{array}{c}\text { Theoretical } \\
\text { stiffness (E) } \\
\text { GPa (msi) }\end{array}$ & $\begin{array}{c}\text { Difference } \\
(\%)\end{array}$ \\
\hline $\begin{array}{c}\text { 3-point } \\
\text { (Section 7.3) }\end{array}$ & $\begin{array}{c}89 \\
(20)\end{array}$ & $\begin{array}{c}14.81 \\
(0.583)\end{array}$ & $\begin{array}{l}1.31 \times 10^{13} \\
\left(4.55 \times 10^{9}\right)\end{array}$ & $\begin{array}{l}1.29 \times 10^{13} \\
\left(4.49 \times 10^{9}\right)\end{array}$ & $27.2(3.94)$ & $26.8(3.89)$ & 1.3 \\
\hline
\end{tabular}

\section{Deflection of FRP wicket gate system due to water load}

Figure 15 shows the distribution of hydrostatic pressure on the upstream $(\mathrm{u} / \mathrm{s})$ and downstream $(\mathrm{d} / \mathrm{s})$ side of the gate during operating position. The maximum deflection at the tip of the gate (free end) occurs when there is full level of water on upstream side and only up to the level of the top hinge (prop location) on the downstream side. After deducting the hydrostatic pressure of the $\mathrm{d} / \mathrm{s}$ side from the $\mathrm{u} / \mathrm{s}$ side, the distribution of load is obtained as shown in Figure 15. For the given load distribution and hinge boundary conditions at $\mathrm{A}$ and $\mathrm{B}$, the deflection at the tip (free end) can be obtained from Eqn. (24), obtained from virtual work principles. The lengths $\left(\mathrm{L}_{1}\right.$ and $\left.\mathrm{L}_{2}\right)$ are shown in the Fig. 16 and the flexural rigidity of the cellular FRP deck with steel fixtures is obtained from section 8 as $1.67 \mathrm{x}$ $10^{13} \mathrm{~N} \cdot \mathrm{mm}^{2}\left(5.82 \times 10^{9} \mathrm{lbf} \mathrm{in}^{2}\right)$.

Deflection at the tip (free end) $(\delta)=\frac{w L_{1}^{3} L_{2}}{24 \mathrm{EI}}-\frac{\mathrm{w} L_{2}^{4}}{30 \mathrm{EI}}-\frac{\mathrm{w} L_{2}^{3} \mathrm{~L}_{1}}{18 \mathrm{EI}}$ 


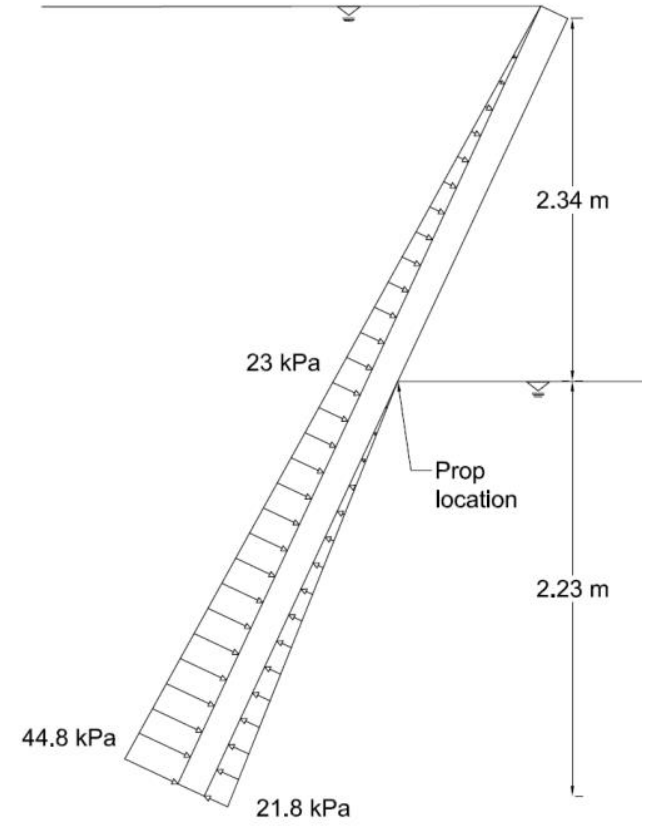

(a)

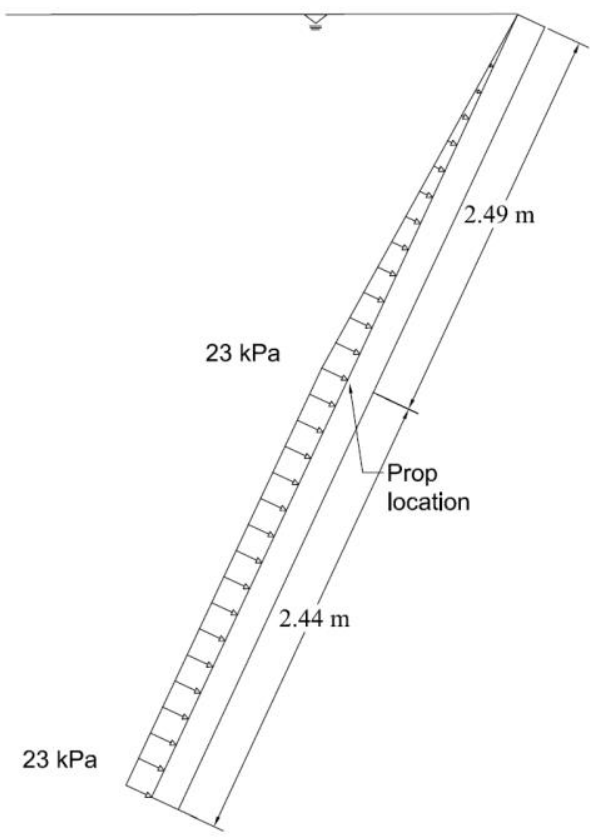

(b)

Fig. 15. Operating position: a) hydrostatic pressure on both sides, b) d/s pressure deducted from u/s pressure

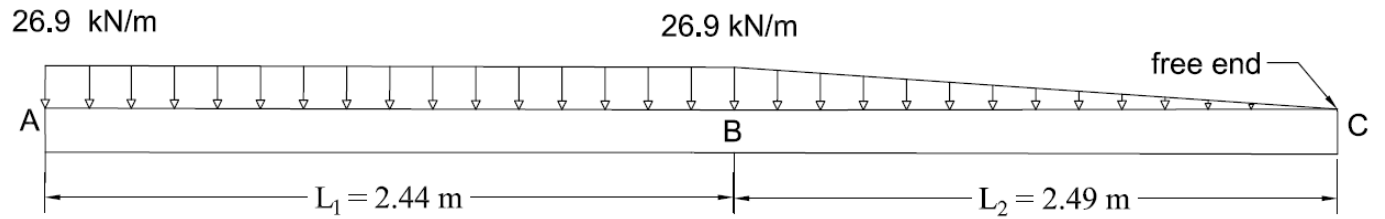

Fig. 16. Loading during operating position of a wicket gate

The deflection obtained from Eqn. (24) is $3 \mathrm{~mm}(0.12$ ") which correlates well with the deflection of $3.11 \mathrm{~mm}$ (0.122") obtained from commercial structural analysis software. The deflection at the free end of the gate is equivalent to the ratio of $(\mathrm{L} / 660)$ for the cantilevered portion of $2.49 \mathrm{~m}$ and is acceptable for field implementation.

\section{Field implementation of FRP wicket gates}

The prop connection zone, shear pins and connecting devices at the base are the most susceptible components in the wicket gate assembly through which loads are transferred from one part to another. At present, connections of the FRP wicket gate at prop location, horse assembly utilize existing steel fixtures. However, it is intended in the future to develop and replace the entire assembly with FRP composites. Four FRP wicket gates were manufactured for field installation. One of these gates had all the existing steel attachments, while the other three gates had no steel angles on the edges of the gate, instead UHMWPE (Ultra high molecular weight polyethylene) plate was bonded on the upstream face and sides of the gates in order to minimize the use of steel attachments and also to monitor the effectiveness of UHMWPE plate on resisting abrasion and barge impacts in comparison to the steel. Figure 17 (a) shows the existing steel angle on the sides of the gate while Fig. 18 (b) shows UHMWPE plate on the sides covering the entire depth. All of the four gates have been installed in Mississippi River at Rock Island lock and dam, IL in August, 2015 as shown in Fig. 18. The monitoring of the gate will be done periodically to establish the relationship between strength and durability. 


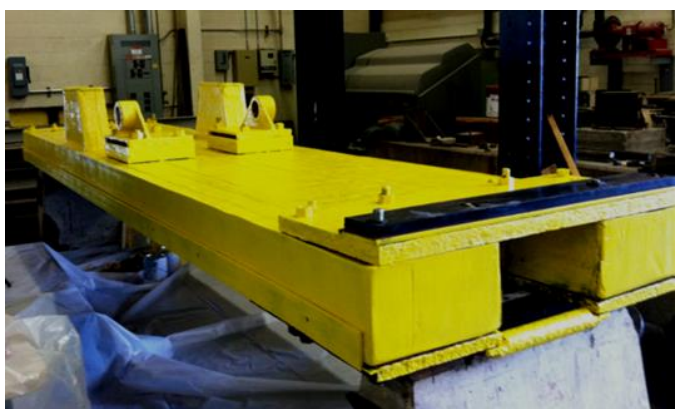

(a)

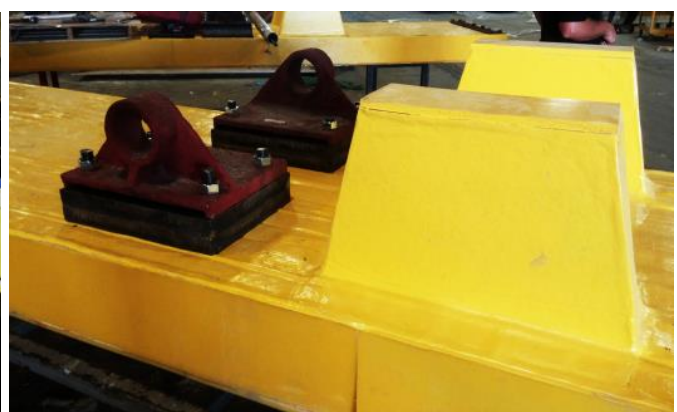

(b)

Fig. 17. FRP wicket gate, a) steel angle on the sides, b) UHMWPE on the sides

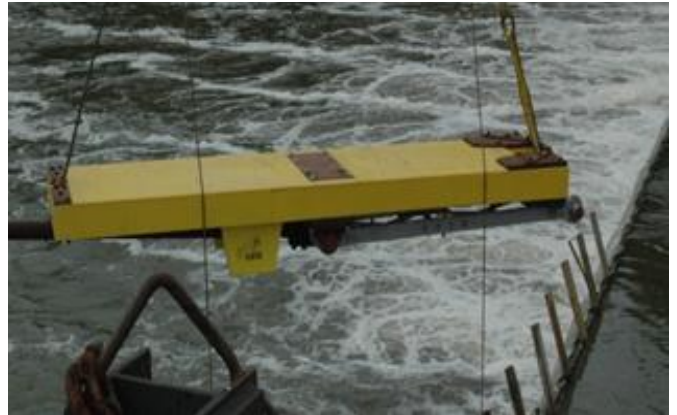

(a)

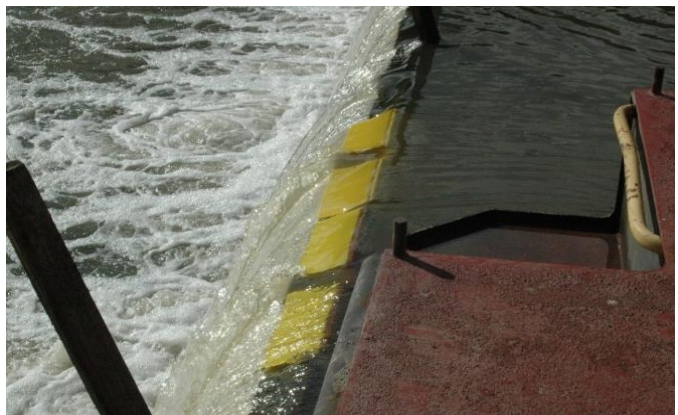

(b)

Fig. 18. Field installation of FRP wicket gates: a) lifting of the gate during installation, b) gates in $65^{\circ}$ position

\section{Conclusions}

Following conclusions are drawn based on the design, testing and evaluation of integrated FRP wicket gates.

1. Integrated FRP wicket gate was successfully developed as a replacement to the existing timber wicket gate consisting of an assembly of several timber leaves and support blocks held together by an assortment of steel plates and angles that are fastened with numerous bolts and welds.

2. Based on the non-destructive bending load tests, FRP gate resisted an applied bending moment of 406.7 $\mathrm{kN}-\mathrm{m}$ (300 k-ft.) with a maximum induced bending and shear strains of 3352 and 2230 micro-strains, respectively. These induced strains are about $1 / 4^{\text {th }}$ to $1 / 3^{\text {rd }}$ of the failure strains.

3. Design factors of safety for the wicket gate in bending, shear, and buckling are in the range of 4.3 to 16.4 .

4. The experimental and theoretical stiffness values of the full-scale cellular FRP sandwich wicket gate without steel fixtures were found to be $27.2 \mathrm{GPa}(3.94 \mathrm{msi})$ and $26.8 \mathrm{GPa}(3.89 \mathrm{msi})$, respectively, showing an excellent correlation between the two.

5. Maximum theoretical deflection of the FRP wicket gate during operating position is $3 \mathrm{~mm}(0.12$ ") at the tip of the gate and corresponds to an acceptable ratio of $\mathrm{L} / 660$ for the cantilevered portion (Fig. 16).

6. The field implementation of the FRP wicket gates was successfully performed. These gates will be monitored periodically to further evaluate their performance under actual field conditions consisting of turbulent water flow. 


\section{Appendix A}

Table A1

Center of gravity of the FRP wicket gate with two embedded steel plates

\begin{tabular}{|c|c|c|c|c|c|}
\hline \multicolumn{2}{|c|}{ Items } & $\begin{array}{l}\text { Dimension } \\
\text { mm (in) }\end{array}$ & $\begin{array}{c}\text { Areas } \\
\mathrm{mm}^{2}\left(\text { in }^{2}\right)\end{array}$ & $\begin{array}{l}\text { Areas in terms of FRP } \\
\mathrm{mm}^{2}\left(\mathrm{in}^{2}\right)\end{array}$ & $\begin{array}{c}\text { CG from x-x, Fig. } 14 \\
\text { mm (in) }\end{array}$ \\
\hline \multirow{2}{*}{$\begin{array}{l}\text { Two embedded } \\
\text { steel plates }\end{array}$} & width & $76.2(3)$ & \multirow{2}{*}{$1452(2.25)$} & \multirow{2}{*}{$11177.4(17.33)$} & \multirow{2}{*}{198 (7.79) } \\
\hline & depth & $9.53(0.375)$ & & & \\
\hline \multirow{5}{*}{ FRP section } & width & $1168(46)$ & \multirow{5}{*}{$\begin{array}{l}57484 \\
(89.1)\end{array}$} & \multirow{5}{*}{$57484(89.1)$} & \multirow{5}{*}{$108(4.25)$} \\
\hline & flange thickness & $13.28(0.523)$ & & & \\
\hline & no. of webs & 14 & & & \\
\hline & web thickness & $10.16(0.4)$ & & & \\
\hline & depth & $215.5(8.5)$ & & & \\
\hline \multicolumn{5}{|c|}{ Center of gravity of cellular FRP gate from bottom $X-X$ (Fig. 14) } & $134.1(5.28)$ \\
\hline
\end{tabular}

Table A2

Composite moment of inertia of FRP gate section with two embedded steel plates

\begin{tabular}{|c|c|c|}
\hline Components of FRP gate cross-section & $\begin{array}{l}\text { Moment of Inertia } \\
\mathrm{mm}^{4}\left(\text { in }^{4}\right)\end{array}$ & $\begin{array}{l}\text { Moment of inertia in terms of FRP } \\
\qquad \mathrm{mm}^{4}\left(\mathrm{in}^{4}\right)\end{array}$ \\
\hline Two embedded steel plates & $5.91 \times 10^{6}(14.2)$ & $42 \times 10^{6}(100.8)$ \\
\hline FRP section & $439.1 \times 10^{6}(1055)$ & $439.1 \times 10^{6}(1055)$ \\
\hline \multicolumn{2}{|c|}{ Total moment of inertia of the FRP deck with two embedded steel plates } & $481.1 \times 10^{6}(1155.8)$ \\
\hline
\end{tabular}

\section{Acknowledgements}

The writers gratefully acknowledge the financial support from US Army Corps of Engineers (USACE). Support from all the engineering and supporting staff of USACE and Rock Island lock and dam site is sincerely acknowledged.

\section{References}

[1] Lampo RG, Marshall OS, Dutta PK. Use of FRP composites in civil works structures. Application of composites in infrastructure renewal and economic development. Polymer Composites II. CRC press. 2001; 235-244.

[2] Report on Failure to act - The economic impact of current investment trends in airports, inland waterways and marine ports infrastructure. ASCE 2012.

[3] Karbhari VM, Zhao L. Use of composites for 21st century civil infrastructure. Computer methods in applied mechanics and engineering 2000; 185.2:433-454.

[4] Van Den Einde L, Zhao L, Seible F. Use of FRP composites in civil structural applications. Construction and building materials 2003; 17.6:389-403.

[5] Lau KT, Zhou LM. Mechanical performance of composite-strengthened concrete structures. Composites Part B: Engineering 2001; 32.1:21-31.

[6] Soti PR. Advanced composites for design and rehabilitation of hydraulic structures. MS thesis. West Virginia University, 2014.

[7] Mouritz AP, Gellert E, Burchill P, Challis K. Review of advanced composite structures for naval ships and submarines. Composite structures 2001; 53.1:21-42.

[8] Shenoi RA, Wellicome JF. Composite materials in maritime structures: Volume 1, Fundamental Aspects. Cambridge University Press 1993. 
[9] Seica MV, Packer JA. FRP materials for the rehabilitation of tubular steel structures, for underwater applications. Composite Structures 2007; 80.3:440-450.

[10] Zorgdrager, A. Feasibility study on the application of fiber-reinforced polymers in large lock gates. PhD diss. TU Delft, Delft University of Technology, 2014.

[11] Lampo, RG, Nosker T, Bamo D, Busel J, Maher A. Development and demonstration of FRP composite fender loadbearing, and sheet piling systems (No. CERL-TR-98/123). Construction engineering research lab (army) Champaign IL. 1998.

[12] Williams JG. Developments in composite structures for the offshore oil industry. In Offshore Technology Conference. Offshore Technology Conference. 1991.

[13] Tomiyama T, Nishizaki I. Applicability of fiber reinforced plastics to hydraulic gates. In Third International Conference on FRP Composites in Civil Engineering. 2006; 13-15).

[14] Gomez ICP. Dynamic behavior of large hydraulic structures in FRP. MS thesis. TU Delft. Delft University of Technology. 2014.

[15] Rossum SV. Road toward a standardized lock gate. MS thesis. TU Delft. Delft University of Technology. 2015.

[16] Krabbe JPV. World's largest FRP composite miter gates for a new lock in the Netherlands. Paper 11. Smart Rivers. Buenos Aires, Argentina. 2015.

[17] Navigation lock and dam. Alternative types of dam gates. Management Measures and Digital Library http://library.water-resources.us/docs/MMDL/FLD/Feature.cfm?ID=7

[18] Chowdhury MR, Davis WG. Olmsted horse wicket experiment in 1: 5-scale hydraulic flume model (No. ERDC-TR-01-11). Engineer research and development center. Vicksburg. MS. 2001.

[19] GangaRao HVS, Vijay PV. Feasibility review of FRP materials for structural applications. Report submitted to US Army Corps of Engineers. 2010.

[20] Chowdhury MR, Hall RL, Davis WG. Flow-induced structural response of a 1:5-scale Olmsted wicket model (No. WES-SL-98-2). Army Engineer Waterways Experiment Station. 1998.

[21] Tripi JM. The applicability of advanced composite structural members, Doctoral dissertation, Massachusetts Institute of Technology. 1999.

[22] Chowdhury MR, Hall RL, Hoffman P. Experimental results for full-scale composite and steel wickets at Smithland facility. Journal of Composites for Construction. 1998; 2.2:69-77

[23] Béjar LAD, Hall RL. Forces on edge-hinged panels in gradually varied flow. Journal of Hydraulic Engineering. 1998; 124.8: 813-821.

[24] American Wood Council. National Design Specification (NDS) Supplement. Design values for wood construction. 2005

[25] March TA, Elder RA. Review of the 1:25 scale hydraulic model Olmsted Wicket Dam. US Army Engineer Division. Ohio River. Contract\# DACW55-92-0187. Cincinnati. OH.1992.

[26] Chowdhury MR, Hall RL. Dynamic performance evaluation of gate vibration. Journal of Structural Engineering. 1999; 125.4:445-52.

[27] Cusen AR, Pama RP. Bridge deck analysis. John Wiley \& Sons. 1975. 
[28] Sridharan S, Zureick AH, Muzzy, JD. Effect of hot-wet environments on E-glass/vinylester composites. In technical papers of the annual technical conference-society of plastics engineers incorporated. Society of Plastics Engineers Inc. 1998; 2:2255-2261.

[29] Iqbal MA. Fatigue life of pultruded and hand lay-up GFRP exposed to different environmental conditions. MS thesis. University of Maine. 2001.

[30] Kelkar AD. Behavior of low cost manufactured thick FRP woven composite laminates under cyclic loading. In FRP Composites in Civil Engineering. Proceedings of the International Conference on FRP composites in Civil Engineering. 2001; 1:235-243.

[31] Mathieson H, Fam A. GFRP polyurethane sandwich panels under reversed bending fatigue. In Advances in FRP Composites in Civil Engineering. Springer Berlin Heidelberg. 2011;164-167. 